\title{
Penerapan Model Quantum Learning pada Pembelajaran IPS Kelas IV SD
}

\begin{abstract}
Author:
Haziza Putri Lestari ${ }^{1}$

Tio Gusti Satria ${ }^{2}$

Andri Valen ${ }^{3}$

Afiliation:

STKIP PGRI

Lubuklinggau

Corresponding email satriagustio@gmail.com

Histori Naskah: Submit: 2022-01-26 Accepted: 2022-01-28 Published: 2022-01-30

Abstrak:

Penelitian ini bertujuan untuk mengetahui hasil belajar IPS peserta didik kelas IV SD Negeri 1 Karya Sakti setelah diterapkan model pembelajaran Quantum Learning secara signifikan tuntas. Setelah dilakukannya uji coba instrumen berjumlah 10 soal dihitung dengan menggunakan uji validitas 8 soal dapat digunakan. Metode yang digunakan eksperimen semu. Desain penelitian one group pre-test dan post-test. Teknik pengumpulan data dengan menggunakan test berbentuk essay berjumlah 8 soal. Populasi dan sampel penelitian berjumlah 23 orang peserta didik yang terdiri dari 10 orang peserta didik perempuan dan 13 orang peserta didik laki-laki kelas IV. Teknik analisis data penelitian menggunakan uji normalitas dan uji-Z dengan taraf $\mathrm{a}=0,05$ diperoleh nilai Zhitung $(3,12)>$ Ztabel $(1,64)$, berdasarkan hasil penelitian penerapan model Quantum Learning dapat meningkatkan minat belajar peserta didik dalam proses pembelajaran, sehingga dapat disimpulkan bahwa terdapat Peningkatan Ketuntasan Secara Signifikan Hasil Belajar IPS Peserta didik Kelas IV SD Negeri 1 Karya Sakti.
\end{abstract}

This is an Creative Commons

License This work is licensed

under a Creative Commons Attribution-NonCommercial 4.0 International License

Kata kunci: Hasil Belajar, IPS, Model, Quantum Learning.

\section{Pendahuluan}

Pendidikan adalah usaha untuk mengembangkan kompetensi akademik peserta didik dan kompetensi nonakademiknya, seperti karakter dan nasionalisme (Silalahi, R. \& Yuwono, 2018). Pendidikan adalah kesadaran dan usaha yang disengaja untuk menciptakan suasana dan proses belajar yang memungkinkan peserta didik untuk aktif mengembangkan potensi dirinya untuk memperoleh kekuatan spiritual keagamaan, pengendalian diri, kepribadian, kecerdasan, budi pekerti, dan keterampilan yang diperlukan dirinya, masyarakat, bangsa, dan negaranya (Estriyanto, Y., Kersten, S., Pardjono, P., \& Sofyan, 2017). Oleh karena itu pendidikan yang diberikan oleh orang dewasa kepada perkembangan proses belajar anak untuk menguatkan pemahaman dan daya ingat perserta didik agar mudah dalam menerima pembelajaran yang diberikan oleh pendidik. Menurut undang-undang No.20 tahun 2003 pendidikan adalah suatu usaha sadar dan terencana untuk mendidik perserta didik yang cerdas dan berkualitas. Perserta didik dapat mengembangkan potensi diri apabila, suasana pembelajaran kelas yang tertib, pengendalian, kepribadian, kecerdasan, ahlak mulia, serta keterampilan dirinya yang diperlukan oleh masyarakat, bangsa dan negara.

Di dunia pendidikan secara keseluruhan pendidik sebagai pemegang peran utama pada saat pembelajaran berlangsung, pendidik yang menentukan berhasil atau tidaknya suatu pembelajaran dalam pendidikan karena pendidik pengorganisasi lingkungan pada saat disekolah, pendidik juga dianggap sebagai petunjuk atau pembimbing kearah pusat-pusat belajar (Zein, 2006). Oleh karena itu pendidik menjadi pihak yang mempengaruhi proses pembelajaran didalam kelas. Sehingga para pendidik dituntut memiliki klasifikasi dan kompetensi tertentu, serta bisa memilih sistem pembelajaran yang tepat untuk mengingatkan motivasi dan aktivitas belajar peserta didik. Namun dalam proses pembelajaran, sering kali disekolah banyak menemukan permasalahan yang harus dihadapi dalam proses pembelajaran adalah anak kurang didorong mengembangkan kemampuannya 
berpikir dan anak cenderung bosan karena perserta didik hanya mendapat materi dengan model konvensional.

Pembelajaran merupakan cara proses interaksi yang terjadi antara peserta didik dengan pendidik untuk saling bertukar informasi atau pembelajaran berserta unsur-unsur berpendapat pembelajaran adalah proses komunikasi antara pembelajar dengan pengajar dan bahan ajar agar peserta didik lebih kreatif, berpikir kritis supaya memperoleh perserta belajar yang tinggi dan terdapat perubahan perilaku positif pada diri peserta didik tersebut (Hujair, 2013).

IPS merupakan mata pelajaran yang diajarkan sampai tingkat sekolah dasar. Namun pada hakikatnya, sudah ditetapkan kepada peserta didik sebelum memasuki sekolah dasar, yaitu melalui pendidikan yang dilakukan oleh orang tua dan pengaruh lingkungan sekitar. Jadi seharusnya dengan menerapkan kebiasaan-kebiasaan hidup yang baik. Pembelajaran IPS di Sekolah Dasar tidak seharusnya diajarkan hanya sebatas materi dan hafalan saja karena materi pembelajaran IPS lebih menekankan pada kehidupan sehari-hari mereka (Nanda Farira, Andriana Sofiarini, 2021).

Model Quantum Learning adalah suatu pengetahuan dan metodologi belajar yang menciptakan pengetahuan deklaratif yang mengenai bagaimana orang melakukan sesuatu yang dirancang secara khusus yang memperlakukan perencanaan dan pelaksanaan yang cukup rinci agar belajar berhasil dan efektif (Porter, 2009). Ada beberapa faktor didalam pembelajaran Quantum Learning yang harus dipenuhi diantaranya pendidik, peserta didik. Pendidik merupakan seorang tenaga pendidik yang pekerjaanya membagikan ilmunya kepada peserta didik. Jika seorang pendidik dapat menyampaikan pembelajaran dengan baik, maka pada pembelajaran Quantum Learning dapat tersampaikan dengan maksimal. Apabila seorang pendidik mengajar tidak sesuai dengan yang diharapkan maka materi tidak akan tersampaikan dengan maksimal pada proses pembelajaran berlangsung. Dengan adanya media pembelajaran pendidik dapat menyampaikan materi secara efektif dan dapat membuat peserta didik lebih aktif pada saat proses pembelajran berlangsung. Apabila didalam proses pembelajaran menggunakan model pembelajaran peserta didik akan senang, tidak mudah jenuh, peserta didik lebih aktif didalam kelas saat belajar.

Analisis yang dilakukan penulis pada tanggal 8 Januari 2021. Kegiatan awal melakukan uji pre-test dengan menggunakan tes soal berbentuk essay yang berjumlah 8 soal diberikan kepada peserta didik kelas IV SD Negeri 1 Karya Sakti. Berdasarkan hasil uji pre-test didapatkan rata-rata nilai 47,30 dengan jumlah peserta didik 23 orang. Metode yang sering digunakan dalam proses pembelajaran metode ceramah, Tanya jawab, penugasan. Proses pembelajaran tatap muka tetapi sistemnya masuk sekolah bergantian dalam kelas jika kelas yang mendapatkan giliran masuk sekolah tatap muka datang kesekolah mengikuti belajar seperti biasanya, apabila kelas yang mendapatkan sekolah daring tetap melakukan pembelajaran tetapi dari rumah. Bahan ajar yang digunakan buku peserta didik dan buku pendidik. Kesulitan peserta didik dalam pembelajaran Quantum Learning yaitu materi yang disajikan sangat terbatas sehingga peserta didik tidak ada kesempatan untuk memperdalam materi pada saat jam pelajaran berlangsung dan terkadang peserta didik bingung apabila disuruh mengerjakan soal-soal dibuku peserta didik yang telah disediakan.

Model Quantum Learning merupakan model belajar kelompok, masing-masing peserta didik dibuat kelompok dalam satu kelompok yang berjumlah 5 sampai 6 orang kemudian pendidik menyiapkan gulungan kertas didalam kertas tersebut berisikan pertanyaan tentang materi yang telah dipelajari sambil menyanyikan satu buah lagu. Model Quantum Learning sangat mudah, praktis dan menyenangkan bisa dilakukan dimana saja. Berdasarkan permasalahan di atas penulis menerapkan model Quantum Learning untuk pembelajaran IPS kelas IV Sekolah Dasar. Oleh karena itu, penulis mengambil judul penelitian yaitu "Penerapan Model Quantum Learning Pada Pembelajaran IPS Kelas IV SD Negeri 1 Karya Sakti". 


\section{Studi Literatur}

Proses pembelajaran yang baik terjadi ketika terjalin komunikasi dimana seorang guru menyampaikan ilmu kepada siswa sehingga tercipta suasana belajar yang menyenangkan (Ernita Sary, Zico Fakhrur Rozi, 2020). Model pembelajaran adalah kerangka konseptual yang menggambarkan prosedur sistematis dalam mengorganisasikan pengalaman belajar guna mencapai tujuan belajar dan seluruh rangkaian penyajian materi ajar yang meliputi segala aspek sebelum sedang dan sesudah pembelajaran yang dilakukan pendidik serta segala fasilitas yang terkait yang digunakan secara langsung atau tidak langsung dalam proses belajar mengajar (Udin, 2016). Model pembelajaran adalah metode yang digunakan selama proses pembelajaran yang dijelaskan dari awal sampai akhir dan biasanya disajikan oleh guru (Mitha Natasya Putri, Aren Frima, 2020).

Model pembelajaran memliliki ciri-ciri adalah sebagai berikut: 1) Berdasarkan teori pendidikan dan teori belajar tertentu. 2) Mempunyai misi atau tujuan pendidikan tertentu. 3) Dapat dijadikan pedoman untuk perbaikan kegiatan pembelajaran di kelas. 4) Memiliki perangkat bagian model (Jauhar, 2014). Model Pembelajaran Quantum Learning adalah suatu pengetahuan dan metodologi belajar yang menciptakan lingkungan belajar yang efektif, merancang kurikulum, menyampaikan isi dan strategi belajar untuk memudahkan proses belajar mengajar yang berhasil dan efektif (Porter, 2009). Model pembelajaran Quantum Learning mempunyai beberapa karakteristik yaitu: 1) Pembelajaran Quantum Learning berpangkal pada psikologi kognitif. 2) Pembelajaran Quantum Learning berupa potensi diri pada manusia. 3) Pembelajaran Quantum Learning memusatkan perhatian pada interaksi yang bermutu dan bermakna (Champ, 2009).

Model pembelajaran Quantum Learning memiliki prinsip yaitu: 1) Mengetahui bahwa segalanya berbicara. 2) Mengetahui bahwa segalanya bertujuan. 3) Menyadari bahwa pengalaman mendahului penanaman. 4) Mengetahui setiap usaha yang dilakukan dalam pembelajaran (Porter, 2009). Langkahlangkah model pembelajaran sebagai berikut: 1) Sesuai dengan tujuan pembelajaran. 2) Mencakup semua apa yang akan dicapai. 3) Pertimbangan tergantung yang ada pada diri peserta didik. 4) Tumbuhkan minat dengan menciptakan suasana belajar yang menggembirakan dengan menggunakan permainan, bernyanyi, agar memuaskan dalam belajar (Champ, 2009).

Kelebihan model pembelajaran Quantum Learning yaitu: 1) Pembelajaran Quantum Learning dapat mengembangkan keterampilan dalam memecahkan masalah. 2) Dapat membuat belajar seseorang menjadi dewasa atau autentik. 3) Pembelajaran Quantum Learning sebagai model pembelajaran yg membuat perserta didik menjadi mandiri (Sudana, I.P.S.,\& Wesnawa, 2010). Model pembelajaran adalah keterampilan guna untuk pemecahan masalah dan berpikir kritis yang dilandasi oleh teori dengan menyajikan permasalahan yang nyata membutuhkan kerjasama antara peserta didik dengan pendidik yang memadukan setiap materi pembelajaran (Weil, 2018).

Model Quantum Learning merupakan model belajar kelompok, masing-masing peserta didik dibuat kelompok kemudian pendidik menyiapkan gulungan kertas didalam kertas tersebut berisikan pertanyaan tentang materi yang telah dipelajari (Mills, 2012). Pembelajaran IPS adalah ilmu pengetahuan yang mengkaji berbagai pembelajaran yang terutama IPS serta mengetahui kegiatan dasar manusia dalam rangka memberi wawasan dan pemahaman yang mendalam kepada peserta didik mampu membina suatu masyarakat yang baik dimana para anggotanya benar-benar berkembang secara sosial yang rasioal dan penuh tanggung jawab dalam menjalankan tugas apapun, dari berbagai cabang seperti ilmu sosial, seperti sosiologi, sejarah, geografi, politik, dan budaya. Oleh karena itu IPS merupakan bagian dari kepribadian seseorang untuk menciptanya akhlak dak kepribadian yang baik terhadap perserta didik (Supadi, 2011).

Tujuan pembelajaran IPS adalah untuk mendidik dan memberi bekal kemampuan dasar kepada peserta didik untuk mengembangkan diri sesuai dengan bakat, kemampuan, bekal perserta didik dimasa yang akan datang (Adelina, 2015). 


\section{Metode Penelitian}

Metode penelitian yang digunakan dalam penelitian ini adalah metode Eksperimen. Metode penelitian Ekprimen adalah metode penelitian yang digunakan untuk mencari perlakuan tertentu terhadap yang lain dalam kondisi yang terkendali (Sugiyono, 2017). Sampel dalam penelitian ini adalah 20 orang peserta didik yang terdiri dari 11 siswa laki-laki dan 9 siswa perempuan. Metode yang dilakukan observasi pengumpulan data dengan menggunakan tes soal berbentuk essay yang bertujuan untuk mengetahui data peserta didik yang akan diteliti dengan menggunakan rumus uji validitas, reliabilita, daya pembeda dan tingkat kesukaran, soal yang diberikan berjumlah 8 butir soal. Sedangkan respon perserta didik bertujuan untuk mengetahui tingkat kepraktisan dari model pembelajaran Quantum Learning. Soal yang digunakan untuk pengumpulan data membuat pertanyaan untuk mengetahui respon pendidik dan perserta didik mengenai pembelajaran yang diberikan dengan menggunakan 8 pertanyaan (Sugiyono, 2016). Diberikannya soal tersebut bertujuan untuk mengetahui kevalidan soal dengan menggunakan model Quantum Learning instrumen yang digunakan soal berbentuk essay. Rumus yang digunakan adalahsebagai berikut:

a. Uji Validitas

Hasil penelitian yang valid bila terdapat kesamaan antara data yang terkumpul dengan data yang sesungguhnya terjadi pada obek yang diteliti. Valid berarti instrumen tersebut dapat digunakan untukmengukur apa yang seharusnya diukur (Jihad A, 2012).

$$
r_{X Y}=\frac{N \sum X Y-\left(\sum X\right)\left(\sum \mathrm{Y}\right)}{\sqrt{\left\{N \sum \mathrm{X}^{2}-\left(\sum X\right)^{2}\right\}\left\{n \sum \mathrm{Y}^{2}-\left(\sum Y\right)^{2}\right\}}}
$$

Keterangan

$\mathrm{N} \quad=$ jumlah peserta didik yang mengikuti

$\mathrm{X}=$ hasil tes IPS yang di cari validitasnya skor butir soal

$\mathrm{Y} \quad=$ nilai rata-rata haran

Rxy =koofisien korelasi antara variable $\mathrm{X}$ dan $\mathrm{Y}$

$=$ perkalian antara $\mathrm{X}$ dan $\mathrm{Y}$

b. Uji Reliabilitas

Reliabilitas adalah pengukuran atau hal yang dapat dipercaya atau indeks yang menunjukan sejauh mana suatu alat ukur dapat dipercaya atau dapat diandalkan. Dalam instrumen reliabilitas adalah sejauh mana pengukuran dari suatu tes tetap konsisten setelah dilakukan berulang-ulang terhadap subjek dan dalam kondisi yang sama (Jihad A, 2012).

$$
r_{11}=\left(\frac{n}{n-1}\right)\left(1 \frac{s_{\mathrm{i}}^{2}}{s_{t}{ }^{2}}\right)
$$

Keterangan:

$\mathrm{N} \quad$ = banyaknya butir soal

si2 = jumlah varian butir

st2 = varians skor total 
c. Daya Pembeda

Daya pembeda merupakan dari butir soal merupakan seberapa jauh kemampuan suatu butir tersebut. Angka yang menunjukan besarnya daya pembeda disebut indeks dekriminasi (Jihad A, 2012).

$$
\mathrm{DP}=\frac{\mathrm{S}_{A}-\mathrm{S}_{B}}{I_{A}}
$$

Keterangan

DP

$=$ daya pembeda

SA $\quad=$ jumlah skor kelompok atas pada butir soal yang diolah

SB

$=$ jumlah skor kelompok bahwa pada butir soal yang diolah

IA $=$ jumlah skor ideal salah satu kelompok pada butir soal yang diolah

d. Tingkat Kesukaran

Tingkat kesukaran digunakan untuk memperolah kualitas soal yang baik, di samping memenuhi validitas dan reabilitas, adalah adanya keseimbangan dan tingkat kesulitan soal tersebut. Butir soal yang baik adalah sedang yang tidak terlalu mudah dan yang tidak terlalu sukar untuk menghitung tingkat kesukaran butir soal menggunakan rumus. Dalam menganlisis instrumen penelitian, penelitian ini menggunakan uji validitas terlebih dahulu, untuk mengetahui valid dan praktis tidaknya suatu instrumen penelitian. Jika instrumen penelitian menunjukan hasil yang benar maka dikatakan valid dan praktis, tetapi jika instrumen penelitian menunjukan hasil di bawah rata-rata maka dikatakan tidak valid (Jihad A, 2012).

$$
\begin{array}{r}
S_{A}+S_{B} \\
\mathrm{TK}=n \text { maks }
\end{array}
$$

Keterangan:

TK : tingkat kesukaran

SA : jumlah skor kelompok atas

SB : jumlah skor kelompok bawah

$\mathrm{N} \quad$ : jumlah peserta didik kelompok atas dan kelompok bawah

Mks : skor maksimal soal yang bersangkutan.

Jadi dalam menganlisis instrumen penelitian, penelitian ini menggunakan uji validitas terlebih dahulu, untuk mengetahui valid dan praktis tidaknya suatu instrumen penelitian. Jika instrumen penelitian menunjukan hasil yang benar maka dikatakan valid dan praktis, tetapi jika instrumen penelitian menunjukan hasil di bawah rata-rata maka dikatakan tidak valid dan praktis.

\section{Hasil}

Setelah penelitian yang dilakukan dengan menggunakan soal kepada 23 peserta didik kemudian diteliti satu persatu dan diberikan penilaian sesuai jawaban peserta didik. Skor yang diperoleh dari penilaian soal essay uji pre-test skor terendah 26 skor tertinggi 75 skor rata-rata nilai 47,30, Setelah 
dilakukannya uji pre-test selanjutnya dilakukan uji Post-test yang mengalami peningkatan hasil belajar peserta didik skor terendah 60 skor tertinggi 100 skor rata-rata nilai 83,48. Nilai ini diperoleh dari pengisian kuesioner penelitian sebagai berikut: 5 (sangat setuju), 4 (setuju), 3 (cukup setuju), 2 (tidak setuju), dan 1 (sangat tidak setuju). Skor yang diperoleh dari penilaian soal untuk kategori penugasan skor terendah 5 , skor tertinggi 12 , jumlah seluruh skor 80 . Nilai yang didapat dari hasil jawaban perserta jika benar mendapat 1 poin dan jika salah mendapat 0 poin.

\section{A. Hasil Belajar Pre-Test}

Tabel 1. hasil Perhitungan Uji Tes Awal (Pre-test)Peserta didik

\begin{tabular}{|l|l|c|}
\hline No. & Kategori & Keterangan \\
\hline 1 & Nilai Minimum & 26 \\
\hline 2 & Nilai Maksimum & 75 \\
\hline 3 & Rata-rata Nilai & 47,30 \\
\hline 4 & Simpangan Baku & 13,47 \\
\hline 5 & Jumlah Peserta didikTuntas didak & 21 \\
\hline 6 & $\begin{array}{l}\text { Jumlah Peserta didik } \\
\text { Tuntas }\end{array}$ \\
\hline & \multicolumn{2}{|c|}{} \\
\hline
\end{tabular}

Berdasarkan hasil perhitungan data yang dilakukan peneliti, dapat dilihat bahwa kegiatan pre-test yang telah dilakukan berjumlah 23 peserta didik diperoleh nilai rata-rata 47,30 dengan nilai tertinggi 75 dan nilai terendah 26 dari seluruh peserta didik kelas IV yang mengikuti pre-test, adapun peserta didik yang mendapatkan nilai sama dengan kriteria ketuntasan (KKM) atau lebih yaitu nilai 72 sebanyak 2 orang, sedangkan peserta didik yang mendapatkan nilai kurang dari 72 sebanyak 21 orang.

\section{B. Hasil Belajar Post-test}

Tabel 2. Hasil Perhitungan Uji Tes Akhir (Post-test) Peserta didik

\begin{tabular}{|l|l|c|}
\hline No. & Kategori & Keterangan \\
\hline $\mathbf{1}$ & Nilai terendah & 60 \\
\hline $\mathbf{2}$ & Nilai tertinggi & 100 \\
\hline $\mathbf{3}$ & Rata-rata nilai & 83,48 \\
\hline $\mathbf{4}$ & Simpangan baku & 17,64 \\
\hline $\mathbf{5}$ & Jumlah Peserta didik Tuntas & 20 \\
\hline $\mathbf{6}$ & Jumlah Peserta didik Tidak Tuntas & 3 \\
\hline
\end{tabular}

Berdasarkan hasil perhitungan data hasil belajar post-tes peserta didik yang berjumlah 23 orang diperoleh nilai rata-rata sebesar 83,48 . Peserta didik yang telah mendapat nilai mencapai kriteria Ketuntasan Minimal $\geq 72$ sebanyak 23 orang $88,9 \%$. Sedangkan peserta didik yang mendapat nilai dibawah Kriteria Ketuntasan Minimal (KKM) sebanyak 3 orang 11,1\%. Jadi dapat disimpulkan bahwa kemampuan peserta didik setelah penerapan model Quantum Learning termasuk dalam kategori tuntas. Berdasarkan hasil rata-rata nilai (pre-test) sebelum pembelajaran dilakukan diperoleh nilai 47,30 sedangkan pada tes akhir (post-tes) rata-rata nilai peserta didik yaitu sebesar 83,48.

\section{Uji Normalitas}

Uji Normalitas setelah dilakukannya perhitungan rata-rata dari simpangan baku dari pre-test dan posttest selanjutnya diadakan uji normalitas yang bertujuan untuk mengetahui kenormalan dari data dalam penelitian. Untuk menghitung uji normalitas data menggunakan rumus uji kecocokan $\chi 2$ (chi-kuadrat) dengan taraf kepercayaan 0,05 . Berdasarkan ketentuan penghitangan statistik mengenai uji normalitas 
data, jika $\chi 2$ hitung $<\chi 2$ tabel maka data berdistribusi normal, dengan 0,05 dan derajat kebebasan (dk $\mathrm{k}-1$ ), dimana $\mathrm{n}$ adalah banyak kelas interval. Berdasarkan pada tabel 4.2 diatas diperoleh $\chi 2$ hitung tes akhir adalah 1,3643 dan nilai $\chi 2$ tabel adalah 9,49. Hal ini berarti $\chi 2$ hitung $<\chi^{2}$ tabel.Dengan demikian kesimpulan bahwa data post-test berdistribusi normal dengan taraf kepercayaan dan $\mathrm{dk}=\mathrm{k}-$ 1, dimana $\mathrm{N}$ adalah banyak kelas interval.

\section{Uji Hipotesis}

Uji Hipotesis dapat diketahui bahwa tes awal dan tes akhir berdistribusi normal maka selanjutnya dilakukan uji hipotesis data hasil tes akhir (Post-test) menggunakan Uji-Z. Hipotesis merupakan jawaban sementara dari satu penilaian. Hipotesis yang diuji dalam bentuk penelitian ini adalah "Hasil belajar IPS peserta didik kelas IV SD Negeri 1 Karya Sakti setelah penerapan model Quantum Learning".

Adapun hipotesis penentuan dalam penelitian ini adalah:

Ho: Ho ditolak.

Ha: Ha diterima.

Dari perhitungan simpang baku populasi tidak diketahui dan data berdistribusi normal, maka dalam penelitian ini pengujian hipotesis menggunakan Uji-Z. Selanjutnya Zhitung dibandingkan dengan Ztabel dengan $\mathrm{dk}=\mathrm{n}-1$ dan taraf kepercayaan yang digunakan adalah dengan ketentuan jika Zhitung Ztabel maka Ha diterima dan Ho ditolak. Berdasarkan analisis data (terlampir), rekapitulasi hasil uji hipotesis Post-test. Pada tabel 4.3 diatas diperoleh $\chi^{2}$ hitung tes akhir adalah 1,3643 dan nilai $\chi 2$ tabel adalah 9,49. Hal ini berarti $\chi^{2}$ hitung $<\chi^{2}$ tabel. Dengan demikian kesimpulan bahwa data post-test berdistribusi normal dengan taraf signifikan dan $\mathrm{dk}=\mathrm{k}-1$, dimana $\mathrm{N}$ adalah banyak kelas interval.

\section{Pembahasan}

Dari hasil pengujian yang dilakukan, didapatkan bahwa penilain penerapan model oleh ahli model berhasil meningkatkan rata-rata dari tes awal 47,30 meningkatkan menjadi 83,48. Hal ini layak diuji cobakan dalam pembelajaran. Hal ini layak untuk uji cobakan dengan revisi sesuai saran tampa menjatuhkan. Berdasarkan data setelah diterapkan model dan dilakukannya uji pre-test dan post-test mengalami peningkatan, menunjukan bahwa dalam penerapan model Quantum Learning yang telah diperbaiki berdasarkan perhitungan data yang diperoleh dengan skor rata-rata 83,48\% dengan kriteria "Sangat Valid" dapat diartikan bahwa penerapan model Quantum Learning layak digunakan.

Pelaksanaan uji pre-test dan post-test yang dilakukan oleh seluruh kelas IV SD Negeri 1 Karya Sakti. Berdasarkan hasil yang telah dilakukan dapat disimpulkan bahwa respon peserta didik dari uji pre-test pada pembelajaran IPS adalah sangat praktis dengan skor rata-rata 47,30\%, sedangakan uji post-test pada pembelajaran IPS adalah dengan skor rata-rata $83,48 \%$. Kemudian uji respon pendidik model Quantum Learning pada pembelajaran IPS adalah sangat memuaskan dengan skor rata-rata $90 \%$. Berdasarkan persentase keseluruhan nilai dari analisis perhitungan uji pre-test dan post-test yang dilakukan, uji kepraktisan model pembelajaran Quantum Learning tergolong dalam kategori sangat praktis dengan persentase $82,5 \%$ artinya model pembelajaran Quantum Learning yang telah diterapkan sudah praktis untuk digunakan dalam pembelajaran.

\section{Kesimpulan}

Proses pembelajaran menggunakan model pembelajaran dapat membantu peserta didik mudah memahami materi. Kevalidan Model Pembelajaran Quantum Learning dinilai melalui hasil validasi para ahli antara lain: ahli model pembelajaran, ahli bahasa, dan ahli materi. Berdasarkan hasil validasi diketahui bahwa Model Pembelajaran Quantum Learning dikategorikan sangat valid dengan persentase kevalidan 82,5\% sehingga Media pembelajaran Quantum Learning pada pemeblajaran 
tematik dikategorikan sangat valid. Kepraktisan Media pembelajaran Quantum Learning yang diperoleh dengan dua tahap uji coba yang meliputi uji coba tes awal (pre-test) dan uji coba tes akhir (post-test) yang dilakukan kelas IV berjumlah 23 orang peserta didik. Berdasarkan hasil uji coba tersebut diketahui respon peserta didik dan pendidik sangat baik yang diartikan bahwa Model Pembelajaran Quantum Learning pada pembelajaran IPS praktis dan mudah digunakan.

\section{Ucapan Terima Kasih}

Penulis mengucapkan terima kasih kepada dosen pembimbing, Bapak Tio Gusti Satria, M. Pd dan Bapak Andri Valen, M. Pd yang telah memberikan arahan dan dukungan sehingga penelitian ini terlaksana dengan baik. Begitupun dengan rekan-rekan tim penelitian yang tentunya sangat berperan penting dalam pelaksanaan penelitian ini. Teruntuk semua pihak yang terlibat dalam proses penyelesaian penelitian ini.

\section{Referensi}

Adelina. (2015). Strategi Pembelajaran Aktif. Insan Madani.

Champ, S. (2009). Pisikologi Pendidikan Teori Dan Praktik. PT Indeks.

Ernita Sary, Zico Fakhrur Rozi, T. G. S. (2020). Application Of Visual Learning Models, Auditory, Kinestetic (Vak) On The Results Of Learning Science Class V Bangunrejo State Elementary School. Literasi Nusantara, 1(1), 51-60. https://doi.org/10.21107/ literasinusantara.v1n1.091105 Estriyanto, Y., Kersten, S., Pardjono, P., \& Sofyan, \& H. (2017). The Missing Productive Vocational High School Teacher Competency Standard in the Indonesian Education System. Journal of Technical Education and Training, 9(1).

https://publisher.uthm.edu.my/ojs/index.php/JTET/article/view/1499

Hujair. (2013). Teori Belajar dan Pembelajaran di Sekolah Dasar. Kencana Peranda Media Grup. Jauhar, H. \&. (2014). an. Model Pembelajaran. Jurnal Ilmiah Sekolah Dasar, 1(1), 1-7.

Jihad A, H. A. (2012). Evaluasi Pembelajaran. Multi Pressindo.

Mills. (2012). Penerapan Model Pembelajaran Team Assisted Individualisation (TAI)Dengan Media

Visual Dalam Peningkatan Pembelajaran Ips Pada Peserta didik Kelas V SD Negeri 2

Karangsari Tahun Ajaran 2015/2016. Cendekia Pgsd Kebumen, 4(3).

Mitha Natasya Putri, Aren Frima, T. G. S. (2020). Application Of The Example Non Example Model In Social Studies Learning For Grade IV Students Of Elementary School 02 Surodadi. Literasi Nusantara, 1(1), 18-28. https://doi.org/https://doi.org/10.21107/literasinusantara.v1n1.091103

Nanda Farira, Andriana Sofiarini, T. G. S. (2021). The Application Of Role Playing Model In Social

Learning On Grade IV Students' At Sungai Hitam Elementary School. Widyagogik, 8(2), 25-31. https://doi.org/https://doi.org/10.21107/Widyagogik/v8i2. 8944

Porter, B. De. (2009). Model Pembelajaran Quantum Learning (Gava Prees (ed.)).

Silalahi, R. \& Yuwono, U. (2018). The Sustainability of Pancasila in Indonesian Education System: A Critical Discourse Analysis of Legal Texts on Education. Research in Social Sciences and Technology (RESSAT), 3(2), 58-78. https://www.learntechlib.org/p/187525/.

Sudana, I.P.S.,\& Wesnawa, I. G. . (2010). Penerapan Model Pembelajaran Kooperatif Tipe STAD Untuk Meningkatkan Hasil Belajar IPS. Jurnal Ilmiah Sekolah Dasar, 7(1), 70-75.

Sugiyono. (2016). Metode Penelitian dan Pengembangan Research and Development ( $\& \& D)$. Alfabeta.

Sugiyono. (2017). Metode Penelitian \& Pengembangan Research and Development. Alfabeta. Supadi. (2011). Teori Belajar dan Pembelajaran di Sekolah Dasar. Kencana Prenada Media Grup. Udin. (2016). Kurikulum 2013 Dalam Prespektif Teori Pembelajaran Konstruktivis. Ta'lim: Jurnal Studi Pendidikan Islam, 1(1), 59-72.

Weil, J. \&. (2018). Model Pembelajaran. (Prada Media Grup. (ed.)).

Zein. (2006). Psikologi Pendidikan. PT Indeks. 